\title{
Fenomena Penyimpangan Profesi Jurnalis
}

\author{
Dadang Rahmat Hidayat dan Aceng Abdullah \\ Program Studi Jurnalistik, Universitas Padjadjaran, Bandung
}

\begin{abstract}
Abstrak
Reformasi di Indonesia membawa iklim demokrasi yang makin terbuka, artinya tidak harus orang yang berasal dari pendidikan jurnalistik, namun saking terbukanya di beberapa tempat tidak ada saringan terhadap profesi ini. Fenomena seperti ini sangat mungkin terbuka adanya potensi penyalahgunaan profesi yang berkedok jurnalis.

Tulisan yang dihimpum melalui action research dengan metode kualitatif ini ini akan mengungkap beberapa fenomena penyalahgunaan profesi wartawan, khususnya untuk memperoleh penghasilan dengan menggunakan profesi wartawan sebagai kedok, antara lain dengan melakukan ancaman memberitakan sesuatu yang dilakukan oleh narasumber atau objek berita yang pada akhirnya meminta sejumlah imbalan agar masalah yang menimpa narasumber tidak dipublikasikan atau meminta paksa profil dan aktivitas narasumber untuk dipublikasikan kemudian meminta jasa atas publikasi tersebut. Kekurangpahaman narasumber atau masyarakat tentang profesi wartawan itu sendiri makin menyuburkan praktek penyimpangan profesi wartawan.
\end{abstract}

Kata Kunci: jumalis, penyimpangan, profesionalisme, sumber berita.

\section{PENDAHULUAN}

Hubungan masyarakat dengan media massa seringkali menjadi masalah yang memiliki potensi konflik. Kondisi ini terjadi pula di Indonesia, terutama pascagerakan reformasi 1998. Pergeseran kekuasaan yang berkembang pada pergeseran konstelasi politik di Indonesia berpengaruh besar pada kebebasan pers.Realitas konflik antara masyarakat dan media massa pun berkembang seiring perubahan kebebasan pers di Indonesia.

Fenomena pers Indonesia era reformasi diwarnai oleh tidak terkendalinya pertumbuhan media (terutama cetak).Profesi wartawan seolah menjadi profesi yang mudah dilakukan orang dengan latar belakang apapun.Begitu mudahnya orang menjadi wartawan sehingga sopir angkot, preman, calo, bahkan pengangguran pun bisamenjadi wartawan.

Di sisi Iain, media baru pada akhirnya berguguran karena tidak mampu bertahan menghadapi persaingan bisnis yang ketat. Uniknya, kematian media massa tersebut tidak mengurangi jumlah wartawan yang "beroperasi". Media baru gampang mati, tapi wartawannya tetap bergentayangan. Bahkan saat bertahan hidup pun, sejumlah media baru tidak menggaji karyawannya sehingga banyak wartawan yang 'digaji' dengan Kartu Pers

Kondisi di atas, seolah melempar tanggung jawab kepegawaian yang harusnya ditanggung oleh perusahaan media,kepada sumber berita. Wartawan diarahkan untuk mencari uang dari kartu pers yang ia miliki. Hal ini yang akhirnya berujung pada upaya pemerasan atau permintaan imbalan saat peliputan berita. Padahal soal kesejahteraan wartawan bukan tanggungjawab sumber berita.

Berlindung kepada undangundang Pers yang menjamin bahwa wartawan dilindungi dalam proses mencari informasi untuk kebutuhan khalayak, serta segala hal yang menghalang-halangi upaya peliputan 
berita dapat dikenakan sanksi pidana, maka seolah profesi wartwan dianggap "sakti" oleh sebagian orang. Tak jarang orang yang berprofesi sebagai wartawan menunjukkan identitasnya saat operasi lalu lintas, dengan maksud agar dibebaskan dari segala pelanggaran yang dilakukan.

Pasal 18 ayat 1 Undang-undang No.40 tahun 1999 tentang Pers (UU 40/1999) mengatur tentang ancaman pidana yaitu setiap orang yang melawan hukum dengan sengaja melakukan tindakan yang berakibat menghambat atau menghalangi pelaksanaan ketentuan Pasal 4 ayat (2) dan (3) dipidana dengan penjara paling lama dua tahun atau denda paling banyak Rp.500.000.000,

Padahal yang dilindungi oleh undang-undang adalah kegiatan jurnalistiknya, sementara segala sesuatu yang diluar kegiatan jurnalistik maka diterapkan undang-undang lain yang berlaku. Seperti upaya pemerasan yang dilakukan oleh wartawan bukan termasuk kegiatan jurnalistik yang dilindungi undang-undang. Maka kegiatan tersebut sudah masuk dalam ranah pidana, dengan ancaman hukuman penjara.

Kebebasan pers pada era reformasi diwarnai dengan merebaknya jumlah organisasi kewartawanan (sampai Juni 2003 tercatat 56 organisasi).Kondisi ini menjadikan muncul persepsi semakin sulit menyelesaikan konflik dengan wartawan karena tidak ada satu organisasi yang bisa dijadikan acuan profesionalisme wartawan.

Dalam era informasi seperti sekarang, konflik antara masyarakat dengan wartawan dalam pelaksanaan kegiatan jurnalistik tidak hanya terjadi di kota besar. Potensi konflik masyarakat dengan media massa pun kerap terjadi di kawasan pedesaan. Hal ini disebabkan oleh ketidaktahuan masyarakat desa termasuk perangkat desa, kepala sekolah, tokoh masyarakat dan pelaku usaha rumahan akan media massa dan para awaknya yang bertugas di lapangan.

Ketidaktahuan masyarakat desa tentang media massa menyebabkan terjadinya gesekan diantara kedua belah pihak, bahkan perangkat desa, kepala sekolah dan pelaku usaha rumahan seringkali menjadi obyek untuk kepentingan tertentu oleh orang-orang yang mengaku sebagai awak atau wartawan media massa, Akibatnya, muncul kesalahan persepsi tentang profesi wartawan ini, dan seringkali dinilai sangat negatif karena ulah sejumlah oknum media tersebut.Orang yang mengakungaku sebagai wartawan namun tidak menjalankan tugas profesi wartawan biasa disebut sebagai wartawan bodrex, wartawan gadungan, wartawan abal-abal, Wartawan Tanpa Suratkabar (WTS), juga wartawan bodong.

Salah satu daerah yang diamati dan berpotensi memiliki permasalahan seperti ini adalah Desa Citali; Kecamatan Pamulihan Kabupaten Sumedang Jawa Barat. Desa Citali Kecamatan Pamulihan, Kabupaten Sumedang merupakan desa dengantingkat pencapaian Indeks Pembangunan Manusia (IPM) masih terbilang rendah untuk tingkat Kabupaten Sumedang. Padahal, desa ini hanya berjarak sekitar tujuh kilometer dari Kecamatan Jatinangor Sumedang, kecamatan tempat bermukim empat perguruan tinggi besar di Jawa Barat. Dalam bidang pendidikan, berdasarkan data terakhir (2013), dari lebih 2000 penduduk usia di atas 18 tahun, hanya 111 orang yang sampai pada pendidikan tinggi. Lebih dari setengah penduduk dewasa hanya lulus pendidikan dasar.

Karena kondisi obyektif seperti itu, desa ini berpotensi besar didatangi para oknum yang mengaku wartawan. Oknum ini mendatangi kantor desa, sekolah, atau kelompok masyarakat desa lainnya. Mereka diancam dan ditakut-takuti dengan berbagai informasi yang belum tentu kebenarannya.Daerah Sumedang menurut studi observasi yang kami lakukan sebelumnya, memang memiliki potensi wartawan bodong yang cukup besar. Hal tersebut salah satunya karena ketatnya upaya penertiban wartawan bodong di Bandung, sehingga daerah sekitar Bandung mendapatkan limpahannya. Selainitu saat berkunjung ke salah satu dinas di kabupaten Sumedang didapati banyak stiker-stiker bertuliskan penolakan terhadap hadirnya wartawan bodong. 
Informasi dari beberapa pegawai di kelurahan, ternyata banyak wartawan bodong yang juga berasal dari Kecamatan Pamulihan. Hanya saja untuk upaya pémberantasannya mereka mengaku tidak tahu dan menyerahkannya kepada pihak yang berwenang.

Citali juga dikenal sebagai daerah industri UMKM penghasil makanan ringan "Telor Gabus" yang menyuplai sejumlah pusat -jajanan di Bandung. Mereka berproduksi secara mandiri dengan mempekerjakan penduduk sétempat. Dalam berproduksi mereka menggunakan bahan bakar gas $3 \mathrm{Kg}$ dan menyisakan limbah cangkang telor. Hal tersebut yang seringkali dijadikan senjata bagi wartawan bodreks untuk menakutnákuti para pengusaha.

Modusnya, mereka datang dengan berkelompok 2-5 orang, dan menyampaikan bahwa pengusaha Citali telah melanggar aturan, sehingga jika mereka beritakan maka potensi diketahui pihak berwenang begitu besar. Sehingga kemungkinan usaha mereka akan ditutup pun sangat mungkin trejadi. Maka untuk mencegah penutupan usaha, mereka menawarkan upaya kompromi untuk tidak memberitakan pelanggaran yang terjadi, dan meminta sejumlah imbalan uang kèpada pengusaha. Nilainya cukup besar. Mereka kadang meminta Rp 5 juta kepada sẹtiap pengusaha.

Oleh karena itu, kepada perangkat désa, kepala sekolah, tokoh masyarakat dan pelaku usaha rumahan, perlu diberi péngetahuan tentang media massa dan profesi para wartawannya sehingga mereka tidak lagi menjadi bulan-bulanan bahkan menjadi obyek pemerasan. Media untuk melakukan semua itu yakni dengan gerrakan journalism literacy atau gerakan melek profesi jurnalis melalui sosialisasi profesionalisme jurnalis/wartawan, péngenalan media massa dan profesi kewartawanan.

\section{REGULASI DAN JAMINAN PROFESINALISME}

Lahirnya Undang-undang nomor 40 tentang Pers membawa era baru bagi perkembangan pers nasional. Era ini dianggap sebagai lahirnya kebebasan pers di Indonesia setalah lebih dari tiga dekade merasa dipasung oleh pemerintahan orde baru.Dituliskan oleh Arinanto dalam bukunya Politik Hukum Pers Indonesia jika yang spektakuler dari Undang-undang Pers ini adalah setiap orang berhak menerbitkan pers tanpa memerlukan SIT dan sejenisnya. Ini artinya akan menjamurnya produk-produk pers yang tidak diimbangi oleh kualitas pendidikan SDM-SDM nya.

Hal ini yang kemudian juga dinilai sebagai salah satu sebab lahirnya wartawan abal-abal, karena untuk mendirikan perusahaan media atau sekedar menerbitkan produk pers tidak dibutuhkan izin. Orang bisa langsung membuat dan mengedarkannya. Maka sejalah dengan menjamurnya perusahaan pers, menjamur pula pekerja-pekerjanya yang dilabeli wartawan. Ada yang semua memang berpendidikan kewartawanan tapi tak sedikit yang mengambil orang seadanya dengan kemampuan yang coba diasah instan.

Maka tak heran jika akhirnya lahir banyak wartawan tak memiliki kemampuan jurnalisme atau bahkan tak mengerti tentang profesi mereka dan aturan-aturan tentang profesi mereka, namun sudah bertugas dalam peliputan berita.

Dalam buku yang lain yang berjudul Potret Jurnalis Indonesia yang diterbitkan oleh AJI, diulas jika berdasarkan Kode Etik Jurnalistik yang mereka keluarkan tidak dibenarkanjika wartawan menerima amplop. Amplop didefinisikan sebagai uang imbalan peliputan, atau fasilitas lain seperti tiket perjalanan, akomodasi dan lain sebagainya. Hal tersebut tidak dibenarkan kaena dianggap akan mampu memengaruhi independensi wartawan.

Sementara Jakob Oetama dalam bukunya Pers Indonesia Berkomunikasi dalam Masyarakat Tidak Tulus menggaris bawahi jika pers merupakan refleksi dari kenyataan masyarakat. Selain itu Jakob juga menyampaikan jika tidak semua peristiwa yang wartawan ketahui atau temukan di lapangan dapat serta merta diterbitkan dalam medianya. Namun harus melalui alur editorial dan proses 
menejemen yang baik. Hal ini tidak relevan dengan ancaman yang biasa dilakukan oleh wartawan bodrex yang akan memuat sisi negatif kegiatan yang mereka jumpai jika tidak ada kompensasi uang sebagai syarat "damai".

Dalam buku yang ditulis oleh Hanif Suranto, Hawe Setiawan, dan Ging Ginanjar berjudul Pers Indoensia Pasca Soeharto dimuat beberapa contoh kasus yang pernah terjadi akibat ulah dari wartawan bodrex. Seperti berikut:

Pada 30 Maret 1998 dua orang mengakuk wartawan "Surabaya Minggu" berhasil memeras Bupati Lombok Barat. Semua mereka didatangi oleh wartawan yang meminta data soal keberhasilan Pemda menangani kasus Gili Tarawang. Tapi ujung-ujungnya mereka meminta uang $\mathrm{Rp} 2$ juta, sebagai uang pelicin bagi penulisan artikel mereka. Kasus ini teraungkap saat Kehumas Lombok Barat melaporkan aksi ini kepada PWI setempat.

Sebelumnya di Bandung juga pernah terjadi tindak pemerasan yang dilakukan oleh wartawan-wartawan yang medianya tidak pernah didengar sebelumnya. Seperti Linggajati, Wahana Indonesia, Tabloid Mingguan Bintang, dan Medan Post. Mereka mendatangi karyawan BAKN Bandung dan meminta uang masingmasing Rp 2 juta untuk empat orang. Namun nahas upaya pemerasan itu dicurigai, dan selanjutnya wartawan tersebut diamankan oleh satpam dan diserahkan ke kepolisian.

Hubungan media adalah sebuah keterampilan yang sangat strategis dalam hal penyebaran informasi melalui media massa. Untuk memperkenalkan potensi sebuah wilayah kepada publik, diperlukan kemampuan untuk menyebarkan informasi secara efektif.Kadangkala, karena hubungan media yang buruk, masyarakat tidak tertarik untuk datang ke wilayah yang berpotensi padahal keadaan aslinya jauh lebih bagus.Karena itu, diperlukan kemampuan yang tinggi di bidang tersebut agar tujuan promosi potensi daerah dapat tercapai.

Melalui ilmu media relations dapat diketahui apa dan bagaimana tugas dan fungsi awak media (wartawan) dalam menjalankan tugasnya, baik dilihat dari tatanan yang ada maupun dilihat dari segi yuridis formal. Selama ini masih muncul anggapan bahwa wartawan media merupakan sosok yang menakutkan dan bisa memberitakan apa saja sehingga kehadirannya acapkali kurang disukai bahkan oleh perangkat desa.

Oleh karena itu, dibutuhkan sebuah upaya untuk memberikan sosialisasi terhadap perangkat desa agar mereka melek terhadap profesi wartawan ini.Kemampuan seperti itu dibutuhkan agar kegiatan prangkat desa dan masyarakat penuh dengan ketenangan tidak terganggu oleh aneka ancaman oleh oknum awak media. Diharapkan setelah itu, mereka akan tumbuh menjadi sumber daya yang memiliki kepedulian sosial yang tinggi.

Dalam sosialisasi ini, para perangkat desa, kepala sekolah, tokoh masyarakat sampai para pelaku usaha kecil tingkat desa diikutsertakan sebagai target pelatihan. Alasan penyelenggaraan kegiatan ini didasari oleh pengakuan pengalaman ketiga kelompok masyarakat Desa Citali tersebut yang sempat merasa dirugikan saat berinteraksi dengan sekelompok orang yang mengaku jurnalis. Sejumlah masalah yang perlu diperhatikan adalah:

1. Adanya keluhan dari perangkat desa tentang oknum-oknum yang mengaku awak media dengan ancaman pemberitaan dan ancaman sanksi hukuman.

Tutur salah seorang warga, bahwa hampir setiap tiga bulan selalu ada wartawan yang datang ke industri mereka, dan meminta sejumlah uang. Semula mereka coba menggertak dengan berbagai permasalahan. Namun pada akhirnya mengajak damai dan meminta sejumlah uang. Selain itu mereka juga datang kepada pejabat kelurahan. Di tingkat ini mereka tak segan pula untuk meminta uang kepada perangkat desa dan bahkan kepada kepala desa.

2. Tidak adanya pendidikan formal tentang komunikasi dan hubungan media yang terjangkau oleh warga lokal. 
Mempelajari tentang seluk beluk media atau wartawan tidak mudah, sehingga pengetahuan tentang profesi wartawan semakin tertutup. Penelitian dan pelatihan ini penting untuk melindungi arapat desa dan pemilik usaha Telor Gabus dari upaya pemerasan yang dilakukan oleh wartawan bodong.

3. Tidak meratanya kemampuan para aparat desa dalam hal komunikasi bermedia sehingga terdapat kemungkinan kesalahan teknis komunikasi.

Dari staf yang ada di desa, tak ada yang tahu persis tentang bagaimana berkomunikasi di media. Padahal jika mereka memahami, maka dapat dijadikan alat untuk menyebarluaskan informasi keberhasilan sebuah desa atau bentuk sosialisasi program kerja kepada warganya.

\section{Mitos Wartawan Dimanipulasi oleh Wartawan Bodrek}

Citra wartawan di mata masyarakat tak terlepas dari berkembangnya mitos tentang profesi ini. Berdasarkan hasil diskusi dengankelompok pengusaha UMKM yang tergabung dalam Kelompok Usaha "Padat karya" Manco, Desa Citali Kecamatan Pamulihan, Kabupaten Sumedang (informan 1); Kepala Sekolah di Kecamatan Pamulihan Kabupaten Sumedang (informan 2); dan aparat desa di Kecamatan Pamulihan Kabupaten Sumedang (informan3), berikut sejumlah mitos wartawan yang mereka ketahui:

1. Wartawan bisa diundang kapan saja,

Hasil perbincangan kepada sejumlah pemuka opini, menunjukkan bahwa kerja wartawan tidak jauh berbeda dengan pekerja panggilan. Mereka bisa dipanggil dan diminta untuk meliput sesuatu, sepanjang disiapkan uang saku atau honor peliputan. Padahal yang benar, wartawan hanya akan meliput jika ditugaskan oleh redaktur atau jika ada peristiwa bernilai berita.

2. Wartawan selalu memberitakan hal negatif,

Imagelain seoarang wartawan yang terbangun di benak masyarakat Citali adalah, wartawan selalu memberitakan hal-hal yang negatif. Bahkan menurut mereka, meskipun tidak ditemukan sisi negatif maka akan terus digali hingga sisi negatif itu muncul. Dahulu memang dipahami jika "Bad News is Good News", namun kini berkembang "Good News is Good news" yang artinya jika hal baik, maka akan tetap diberitakan sebagai hal baik, untuk membangun optimisme publik.

3. Wartawan selalu komersial, Setiap kerja wartawan dianggap selalu berujung pada permintaan uang kepada sumber berita. Artinya setiap berita yang dibuat akan ditukar dengan sejumlah rupiah. Padahal soal gaji dan kesejahteraan wartawan bukan tanggungjawab sumber berita, melainkan tanggungjawab perusahaan pers. Selain itu prinsip kerja jurnalis tidak semata-mata karena uang/gaji, bahakan lebih mengedepankan unsur idealisme untuk menyampaikan kebenaran kepada khalayak.

4. Wartawan selalu urakan,

Tingkahlaku wartawan nampaknya juga menjadi sorotan warga Citali. Menurut mereka wartawan cenderung urakan dan tak tahu sopan santun. Misalnya untuk berbicara dengan yang lebih tua, mereka menggunakan nada tinggi. Selain itu, saat memasuki kawasan industri mereka tanpa mengucapkan salam atau "punten".

5. Wartawan manusia pintar,

Wartawan kadang dicitrakan sebagai manusia yang tahu segalanya. Segala informasi yang disampaikan wartwan dianggap sebuah wahyu yang tak boleh dibantah. Padahal dalam 
kenyataanya tak semua wartawan, apalagi wartwan bodong, memiliki pengetahuan yang baik. Seringkali pasal-pasal yang mereka gunakan untuk mengancam warga, hanya sebuah bualan yang tak diketahui sumbernya.

6. Wartawan yang membutuhkan berita,

Relasi yang baik antara wartawan dan sumber berita akan mampu membangun sinergitas yang baik. Wartawan memang memiliki tugas untuk mencari informasi sebagai bahan pemberitaan, tetapi sumber berita juga membutuhkan pemberitaan sebagai upaya sosialisasi kebijakan, program, atau bahkan mengenalkan produk yang mereka miliki. Maka dalam hal ini tergambar jika wartawan dan sumber berita saling membutuhkan.

7. Wartawan kebal hukum,

Undang-undang pokok pers mencantumkan beberapa pasal yang melindungi tugas wartawan dalam mencari sampai menyebarkan informasi. Namun segala hal yang tidak berkaitan dengan tugas wartawan, dan melanggar aturan hukum yang lain maka tetap berlaku aturan undangundang yang lain. Jika wartawan tidak memiliki SIM (Surat Izin Mengemudi) dan terjaring razia, maka baginya tetap diberlakukan aturan yang berlaku dengan tetap diberikan "tilang".

8. Wartawan sosok yang menakutkan,

Mendengar kata wartawan, kadang sejumlah pejabat daerah merasa alergi. Jangankan bisa menjalin relasi, menemuinya saja mereka enggan. Wartawan dianggap sebagai orang yang mencaricari masalah. Sehingga berteman dengan wartawan dianggap sebagai mencari masalah. Sejatinya wartawan hanyalah manusia biasa, yang sedang bertugas menjalankan kewajiban profesinya yaitu untuk mencari dan mengabarkan kebenaran.
9. Wartawan bisa menulis apa saja, Masyarakat menganggap, jika media tempat mereka bekerja dapat memberitakan apapun yang ditulis oleh wartawan. Padahal jika dalam media profesional, alur berita dari wartawan sampai diterbitkan, masih harus melalui sejumlah editor. Mulai dari redaktur, redaktur pelaksana, hingga pemimpin redaksi. Selain itu banyak aturan pula yang membuat wartawan tidak dapat bertindak semaunya. Ada Undangundang Pers, Undang-undang Penyiaran untuk media elektronik, kode etik jurnalistik, sampai Pedoman Perilaku Penyiaran dan Standar Program Siaran (P3SPS) bagi insan penyiaran.

10. Wartawan manusia sakti.

Dikira segala urusan akan selesai jika seseorang mengaku sebagai wartawan. Tak perlu menggunakan helm saat mengendarai motor, tak perlu membayar cicilan kendaraan yang ia kredit, segala urusan selalu ingin diprioritaskan, dan masih banyak persepsikeliru lain tentang wartawan. Faktanya tak semua urusan mampu diselesaikan dengan hanyak mengaku wartawan, atau mengaku kenal dekat dengan pejabat. Semua harus mengikuti prosedur yang berlaku di daerah masing-masing.

Mitos yang berkembang ini kemudian diakui seluruh kelompok informan mempengaruhi sikapmereka saat berinteraksi dengan orang yang mengaku wartawan (baik wartawan asli maupun wartawan gadungan). Terlebih, paparnya, kedatangan orang yang mengaku wartawan kebanyakan sambil membawa "issue" yang mengancam kelangsungan pekerjaan atau usaha mereka.

Sepanjang tahun 2014, kelompok informan 1 mengakui setidaknya mereka menerima tiga kelompok orang yang mengaku wartawan dengan membawa issue berbeda, meliputi penggunaan gas berukuran $3 \mathrm{~kg}$ untuk UMKM; peringatan HUT PWI dan pengelolaan limbah telur di 
pusat produksi cemilan telur gabus.Akibat "issue" yang dibawa orang yang mengaku wartawan cenderung menunjukkan kesalahan atau hal negatif yang dilakukan sumber berita, kelompok ini menganggap wartawan sebagai sosok yang menakutkan dan harus segera diakomodasi keinginannya. Hanya dua orang dari 15 orang anggota kelompok informan 1 yang mengaku berani melawan dan menolak keinginan orang yang mengaku wartawan.

Bahkan satu orang tersebut mengaku sudah kesal dengan ulah wartawan gadungan, yang selama ini dinilai memeras mereka. Ia menuturkan jika datang wartawan gadungan ke tempat usahanya, ia tak segan untuk menantang wartawan tersebut membuka permasalahan yang mereka temukan. Bahkan kadang, karena sudah jengkel, ia menantang untuk berkelahi dengan si wartawan gadungan. Atau bahkan bèrbalik mengancam akan memukuli rame-rame wartawan gadungan yang dianggap meresahkan. Meskipun hal tersebut juga tidak dibenarkan, karena main hakim sendiri.

Pada kelompok informan 2, "issue" yang diusung orang yang mengaku wartawan terkait pengelolaan keuangan sekolah seperti pencairan dana BOS, penempatan jabatan pengelola sekolah dan fasilitas pendidikan. Kelompok ini mengakui setidaknya setiap periode tiga bulan didatangi sekelompok orang yang mengaku wartawan.

Kelompok informan 3 mengaku didatangi kelompok orang yang mengaku wartawan dengan pola berbeda. Mereka diminta untuk membeli sejumlah eksemplar koran atau tabloid secara paksa.

Berikut strategi wartawan bodrek dalam melakukan aksinya:

1. Menyodorkan kasus, lalu mengajak damai

Datang ke sumber berita kemudian menyampaikan sejumlah permasalahan yang berpotensi akan mendera sumber berita akibat sejumlah pelanggaran yang dilakukan. Dengan berbagai bukti yang sudah disiapkan dan sejumlah aturan yang menjeratnya, maka ia mulai meneror sumber berita dengan memberikan satu pilihan solusi yaitu jalan "damai" dengan permintaan uang tutup mulut.

2. Menyodorkan proposal : rapat kerja, kontrakkantor, dll.

Seringkali proposal fiktif dibuat oleh wartawan gadungan untuk kemudian dikirim kepada sumbersumber berita, agar membantu memberikan sumbangan atau bertindak sebagai donatur dalam kegiatan yang tercantum dalam proposal. Kadang juga dengan modus ada kegiatan di tempat wartawan bekerja, dan membutuhkan sokongan dana dari sumber berita. Lagi-lagi semua dilakukan dengan paksaan dan ancaman tertentu.

3. Iklan tembak: memuat iklan terlebih dahulu, lalu menagih ke lembaga yang bersangkutan.

Iklan dalam media profesional adalah salah satu sumber pemasukan yang hasilnya digunakan untuk biaya operasional perusahaan sampai dengan meningkatkan kesejahteraan karyawannya. Dalam praktiknya, iklan dipasarkan oleh seorang marketer yang jika disepakati oleh pengiklan maka iklan baru bisa ditayangkan. Hanya saja ulah wartawan gadungan, yaitu dengan langsung menayangkan iklan tanpa ada konfirmasi ke pengiklan, dan selanjutnya membawa bukti iklan untuk ditagih pembayarannya.

4. Meminta jatah rutin: Bulanan atau THR

Beberapa wartawan gadungan, sengaja meminta jatah kepada lembaga pemerintah atau perusahaan dengan dallih untuk mengamankan pemberitaan. Bentuknya bisa jatah rutin setiap kegiatan, bulanan, atau juga pertahun yang biasanya mereka sebuat sebagi uang THR. Permintaan uang THR oleh wartawan gadungan ini marak terjadi saat menjelang Hari Raya Idul Fitri. 
5. Meminta SPJ liputan ke daerah. Proses peliputan berita dan biaya operasionalnya merupakan tanggungjawab perusahaan media bersangkutan. Hanya saja modus wartawan gadungan, yaitu dengan datang ke perusahaan-perusahaan atau lembaga pemerintah untuk meminta uang saku atau bahkan biaya perjalanan liputan ke luar kota atau bahkan luar provinsi.

6. Menjual paksa: Memuat dahulu berita,lalu menjual paksa medianya.

Sejatinya informasi adalah kebutuhan yang pemenuhannya tidak dapat dipaksakan. Artinya untuk memeroleh informasi dari media, masyarakat tidak seharusnya dipaksa untuk membeli media tersebut. Hanya saja yang sering dilakukan oleh wartawan gadungan, adalah dengan membawa medianya (paling sering media cetak) untuk dipaksakan agar dibeli oleh sumber berita, dengan harga yang cukup mahal dengan alasan sebagai pengganti biaya cetak dan produksi.

7. Jasa pemuatan: Setelah memuat berita, meminta jasa pemuatan.

Wartawan datang untuk melakukan peliputan berita, namun mereka meminta sejulah uang jika sumber berita ingin beritanya dimuat atau disiarkan. Atau bisa juga mereka datang ke sumber berita setelah beritanya terbit atau disiarkan.

8. Memaksa wawancara : Ujungujungnya minta diberi ongkos.

Mereka datang ke semua acara/event yang mereka jumpai. Tidak ada urusan dengan topik dan nilai berita yang ada dalam acara tersebut. Mereka mencari ketua panitia untuk dipaksa diwawancarai. Usai wawancara mereka meminta ongkos untuk pemuatan berita, atau bahkan ongkos untuk pulang ke rumah.

9. Membawa surat keterangan atau foto bersama pejabat tinggi.

Berkembangnya teknologi informasi, membuat orang kini dengan mudah melakukan foto bersama pejabat tinggi dan orangorang berpengaruh lainnya. Pejabat tinggi yang ada di dalam foto tersebut kemudian diakui sebagai orang dekatnya yang mampu membuat keputusan berbahaya jika permintaan si wartawan gadungan tidak dituruti oleh sumber berita.

10. Alasan lain : Pulang kampung, motor rusak, anak sakit, dll.

Terakhir, permasalahanpermasalahan lain yang sebenarnya adalah urusan pribadi wartawan, kadang ikut dibebankan kepada narasumber berita. Sepeti biaya pulang kampung, kerusakaan pada kendaraan, hingga anggota keluarga yang sakit. Mereka meminta biaya kepada relasi atau sumber berita dengan cara halus maupun dengan cara paksa.

\section{"Senjata" Hukum Wartawan Bodrek.}

Fenomena berkembangnya wartawan bodrek padadasarnya memanfaatkan sejumlah peraturan perundang-undangan yang berlaku terkait pers, meliputi:

- Pasal 4 UU No.40 Tahun 1999 tentang PERS :

(2): Terhadap pers nasional tidak dikenakan penyensoran, pembredelan dan pelarangan penyiaran.

(3):Untuk menjamin kemerdekaan pers, pers nasional mempunyai hak mencari, memperoleh dan menyebarkan gagasan dan informasi.

- Ketentuan Pidana ayat 1 Pasal 18 UU No.40 Tahun 1999 tentang PERS : 
"Setiap orang yang secara melawan hukum dengan sengaja melakukan tindakan yang berakibat menghambat atau menghalangi pelaksanaan ketentuan Pasal 4 (2) dan ayat (3) dipidana dengan pidana penjara paling lama 2 (dua) tahun atau denda paling banyak Rp 500.000.000,00 (lima ratus juta rupiah)"

Beberapa pasal di atas, yang biasa digunakan oleh wartawan bodrek untuk memeras sumber berita. Hanya beberapa kalimat, yang tentu saja bisa dihafal dengan cepat dan mudah. Namun mereka tak memahami lebih dalam tentang aturan yang lain, yang menjelaskan tentang bagaimana wartawan harus bekerja secara profesional. Seperti yang tertulis dalam Pedoman Prilaku Penyiaran dan Standart Program Siaran (P3SPS) atau aturan lain berupa Kode Etik Jurnalistik menjelaskan tentang standar profesionalisme kerja seorang wartawan. Beberapa wartawan sendiri banyak yang tidak mengetahui atau memahami bahwa Wartawan Indonesia tidak menyalahgunakan profesi dan tidak menerima suap, yang ditafsirkan adalah segala tindakan yang mengambil keuntungan pribadi atas informasi yang diperoleh saat bertugas sebelum informasi tersebut menjadi pengetahuan umum.Suap sendiri ditafsirkan sebagai segala pemberian dalam bentuk uang, benda atau fasilitas dàri pihak lain yang mempengaruhi independensi.

Penyalahgunaaan profesi wartawan bisa terjadi akibat kurangnya informasi akan hal tersebut, lemahnya penegakan aturan bagi wartawan senior yang melanggar, atau bisa juga karena himpitan ekonomi keluarga. Hal itu diwujudkan dèngan upaya meminta upah kepada sumber berita sesaat setelah wawancara dilakukan, atau bisa jadi mengaku wartawan agar dibebaskan dari sanksi ketika melakukan sebuah pelanggaran.

Mengapa wartawan tidak diperkenankan menerima amplop/ uang atau pemberian sumber berita, karena hal tersebut dikhawatirkan akan berpengaruh terhadap independensi wartawan, maupun independensi perusahaan. Sehingga akan mempengaruhi isi berita ataupun perspektif berita yang disajikan.

\section{Prinsip Menghadapi Wartawan \\ Bodrek}

Berdasarkan hasil FGD yang dilakukan terhadap tiga kelompok informan, dirumuskan lima prinsip menghadapi wartawan bodrek. Kelima prinsip ini diharapkan dapat menghentikan aksi wartawan bodrek di masyarakat. Berikut kelima prinsip yang disosialisasikan dalam gerakan sosialisasi profesi wartawan:

1. Terimalah wartawan sejauh untuk kepentingan tugas jurnalistik.

Jika ada yang datang dan mengaku wartawan, maka terlebihdahulu tanyakanlah apa kepentingannya. Jikka kepentingannya berkaitan dengan tugas profesinya, makapersilahkan dengan baik. Sementara jika tidak berkaitan dengan profesinya, tolaklah.

2. Layani wartawan sejauh hanya untuk minta informasi.

Jika kebutuhan wartawan yang datang hanya meminta informasi maka perlu dilayani dengan baik dan diberikan informasi secukup-cukupnya

3. Mulailah dengan kebiasaan tidak memberikan amplop kepada wartawan seusai wawancara atau pada acara apa pun.

Sekali kita memberikan uang kepada wartawan gadungan, maka keesokan harinya akan banyak wartawan gadungan lain yang datang dan berharap mendapatkan uang serupa. Selain itu, Anda juga bisa menjadi "ATM" atau sumber keuangan bagi wartawan gadungan tersebut.

4. Melaporlah kepada polisi jika merasa diperas oleh wartawan. (selama 2011 belasan wartawan diadili di seluruh Indonesia)

Jika tindakan yang dilakukan oleh wartawan sudah diluar tugas jurnalistiknya, seperti pemerasan, maka jangan takut untuk melaporkannya kepada kepolisian. Karena apa yang ia lakukan tak lagi dilindungi oleh undang-undang, tetapi sudah tindakan kriminal 
5. Berkoordinasilah dengan organisasi wartawan yang resmi dan kompeten. Organisasi wartawan yang kompeten seperti Asosiasi Jurnalis Independen (AJI) dan Persatuan Wartawan Indoneisa (PWI) dapat Anda mintai informasi jika menemui kasus pemerasan yang dilakukan oleh seseorang mengaku wartawan. Mereka dapat memberikan sanksi kepada wartawan yang dinilai melanggar aturan perundang-undangan yang berlaku.

\section{DISKUSI}

Masalah wartawan bodrek ini cukup menggangu psikologi korbannya. Mereka menyampaikan jika pernah suatu ketika datang sekelompok wartawan yang memberikan ancaman dan diakhiri dengan tawaran damai dan permintaan sejumlah uang. Karena merasa nilai yang ditawarkan terlalu tinggi, maka mereka hanya memberikan $\mathrm{Rp} 2$ juta untuk semua pabrik. Namun nyatanya uang tersebut tetap diterima sebelum akhirnya mereka meninggalkan lokasi. Kekhawatiran mereka adalah, jika suatu saat nanti wartawan bodrex tersebut kembali datang dan meminta sejumlah uang kembali.

Jika mereka datang, warga mengaku siap untuk mengahadapi. Mulai dari menolaknya secara halus, sampai dengan menentang segala upaya pemerasan dengan ancaman balik. Meski tentu hal tersebut juga tidak dibenarkan. Para peneliti menyarankan jika hal tersebut berulang kembali, maka lebih baik mereka memberikan penjelasan kritis tentang tugas profesi wartawan, atau jika tetap melakukan upaya pemerasan, maka lebih baik melaporkannya kepada penegak hukum, polisi.

Sesungguhnya modus lama yang digunakan oleh wartawan-wartawan bodong, namun bagi mereka adalah hal baru karena baru pertama kali dijumpai. Seperti kedatangan wartawan bodrex yang semula hanya $1-5$ orang, namun ketika yang datang pertama dituruti kemauannya, makawartawan abal-abal yang lain bergantian datang. Selain FGD kami akhirnya juga membagikan beberapa poster yang berisi tentang aturan-aturan kerja profesional wartawan, yang bisa ditempel di gerbang masuk tempat usaha masing-masing. Hal tersebut diharapkan mampu membuat wartawan abal-abal merasa malu ketika melihat tulisan tulisan tersebut berada di pintu-pintu tempat usaha di Citali. Selebihnya berharap bahwa mereka menyadari apa tugas dan fungsi jurnalis. Hal tersebut membuat masyarakat menjadi melek akan profesi jurnalis. Tidak lagi menganggap jurnalis sebagai profesi yang menakutkan dan sumber bencana. Karena dalam pesan yang ada di dalam poster, tertulis jika wartawan memang tidak dibenarkan menerima imbalan dari sumber berita. Bahasa yang digunakan dalam poster juga bahasa sehari-hari yang mampu dipahami dengan mudah oleh warga masyarakat.

\section{SIMPULAN}

Dari penelitian yang kami lakukan di Desa Citali Kecamatan Pamulihan Kabupaten Sumedang, maka kami simpulkan beberapa hal berikut:

1. Permasalahan wartawan bodrek terjadi di hampir semua daerah. Umumnya mereka melakukan aksinya dengan modus ancaman terhadap sumber berita, dikaitkan dengan potensi kasus yang bisa diungkap . Namun pada ujung pembicaraan mereka menawarkan solusi dengan membayar sejumlah uang, dengan jaminan tidak akan diberitakan.

2. Masalah wartawan bodrex seringkali menimpa korban dari kalangan pengusaha kecil, aparat desa, guru SD, hingga pengelola event.

3. Wartawan borex seringkali menggunakan ayat 1 Pasal 18 UU No.40 Tahun 1999 tentang PERS sebagai dasar hukum membenarkan tindakan mereka.

Penanganan permasalah wartawan bodrex bisa dilakukan dengan sosialisasi menerus tentang profesi wartawan kepada masyarakat, serta melaporkan kepada polisi jika ada tindakan yang dilakukan wartawan di luar tugas jurnalistiknya. 


\section{Daftar Pustaka}

A ianto, Satya. 2005. Politik Hukum Pers Indonesia. Jakarta: Grasindo.

Oetama, Jakob. 2001. Pers Indonesia Berkomunikasi dalam Masyarakat Tidak Tulus. Jakarta: Penerbit Buku Kompas.

Suranto, Hanif. 1999. Pers Indonesia Pasca Soehato, Setelah Tekanan Penguasa Melemah. Jakarta: Penerbit LSPP.

AJI. 2005. Potret Jurnalis Indonesia. Jakarta: Aliansi Jurnalis Independen.

ISAI. 2006. Etika Jurnalisme. Jakarta: Isntistut Studi Arus Informasi

Harahap, Krisna. 200o. Kebebasan Pers di Indonesia Dari masa ke masa. Bandung: Grafitri
Masduki. 2004. Kebebasan Pers dan Kode Etik Jurnalistik. Yogyakarta: UII Pers.

Abidin, Hamid, dan Kurniawati. 2004. Galang Dana Ala Media Strategi Efektif Mengumpulkan Dana Masyarakat. Jakarta: Piramedia

Kovach, Bill, dan Tom Rosenstiel. 2003. Elemen-elemen Jurnalisme. Jakarta: Institut Studi Arus Informasi.

Referensi lain:

Undang-Undang RI No. 40 tahun 1999 tentang Pers

Kode Etik Jurnalistik 
Jurnal komunikasi, Volume 10, Nomor 1, Oktober 2015 